\title{
'Classical' but not 'other' mutations of EGFR kinase domain are associated with clinical outcome in gefitinib-treated patients with non-small cell lung cancer
}

\section{AG Pallis ${ }^{1,6}$, A Voutsina ${ }^{2,6}$, Ar Kalikaki ${ }^{2}$, J Souglakos', E Briasoulis ${ }^{3}$, M Mrray $^{4}$, A Koutsopoulos ${ }^{5}$, M Tripaki ${ }^{2}$, E Stathopoulos ${ }^{5}$, D Mavroudis ${ }^{1,2}$ and V Georgoulias*,1,2}

'Department of Medical Oncology, University General Hospital of Heraklion, Heraklion, Greece; ${ }^{2}$ Laboratory of Tumor Cell Biology, School of Medicine, University of Crete, Heraklion, Greece; ${ }^{3}$ Department of Medical Oncology, University General Hospital of loannina, loannina, Greece; ${ }^{4}$ Department of Molecular Biology and Genetics, Metropolitan Hospital, Athens, Greece; ${ }^{5}$ Department of Pathology, University General Hospital of Heraklion, Heraklion, Greece

'Classical' mutations in the EGFR tyrosine kinase domain (exons 18, 19 and 21) have been associated with sensitivity to tyrosine kinase inhibitors (TKIs) in patients with NSCLC. The aim of the current study was to evaluate whether other than the classical G7I9X, DEL 19 and L858R mutations of EGFR confer sensitivity to TKIs. Genomic DNA was extracted from microdissected formalinfixed paraffin-embedded tumour tissue from 86 patients treated with gefitinib. Exons 18, 19 and 21 were amplified and subjected to direct sequencing. Eleven (13\%) patients harboured the classical exon's 18, 19 and 21 mutations, while I4 (I6\%) had 'other' variants. There was a significantly higher percentage of 'never-smoker' patients with 'classical' EGFR mutations $(P=0.002)$. Among patients with 'classical' mutations 3 patients achieved PR and 7 SD, while in the 'other' mutations group 10 patients had SD as best response. In the wild-type group, there were 3 patients with PR and 25 with SD. Median TTP was 16, 64 (P=0.002) and 2I weeks and median survival was 36, 78 and 67 weeks for patients with wild-type, 'classical' and 'other' EGFR mutations, respectively. The clinical relevance of 'other' EGFR mutation variants remains uncertain and requires further assessment in a prospective study.

British Journal of Cancer (2007) 97, I560-1566. doi:I0.1038/sj.bjc.6604068 www.bjcancer.com

Published online 13 November 2007

(C) 2007 Cancer Research UK

Keywords: NSCLC; EGFR; gefitinib; EGFR mutations

Despite the use of newer chemotherapeutic agents, survival of patients with advanced/metastatic NSCLC after first- or secondline chemotherapy seems to have reached a plateau (Carney, 2002). Further improvement in treatment is likely to require integration of novel, molecular agents such as EGFR inhibitors. The BR.21 placebo-controlled trial of erlotinib demonstrated that therapy with this EGFR tyrosine kinase inhibitor (TKI) was associated with statistically significant and clinically relevant differences in terms of overall and progression-free survival compared to the placebo (Shepherd et al, 2005). Conversely, in a similar study with gefitinib, (ISEL trial), a survival benefit was not demonstrated (Thatcher et al, 2005). Several clinical factors have been correlated with response to TKIs, including never-smoking status, female sex, Asian ethnicity and adenocarcinoma histology (Fukuoka et al, 2003; Kris et al, 2003; Miller et al, 2004; Shepherd et al, 2005). In addition, several groups have shown that somatic mutations in the

*Correspondence: Dr V Georgoulias, Department of Medical Oncology, University General Hospital of Heraklion, PO Box 1352, Heraklion, Crete 7II 10, Greece; E-mail: georgsec@med.uoc.gr

${ }^{6}$ Drs AG Pallis and A Voutsina have contributed equally to this work. Received 10 July 2007; revised 8 October 2007; accepted 9 October 2007; published online 13 November 2007 tyrosine kinase domain of the EGFR gene, in the exons 18 (G719A/ C/S), 19 (DEL19, in-frame deletions which eliminate four to six amino acids just downstream of a critical lysine residue at position 745) and 21 (L858R) (commonly reported as 'classical' mutations), were significantly correlated with clinical response to gefitinib therapy (Lynch et al, 2004; Paez et al, 2004; Eberhard et al, 2005; Tsao et al, 2005). Patients with 'classical' EGFR mutations exhibit objective responses ranging from 75 to 95\% (Huang et al, 2004; Han et al, 2005; Mitsudomi et al, 2005; Taron et al, 2005; Tokumo et al, 2005; Inoue et al, 2006; Yoshida et al, 2007). Furthermore, recently it was reported that polysomy or amplification of the EGFR gene but not EGFR mutational status was associated with clinical outcome of patients treated with erlotinib (Hirsch et al, 2005; Tsao et al, 2005; Dziadziuszko et al, 2006).

Although classical EGFR mutations are present in most cases of NSCLC responding to TKIs therapy, approximately $10-20 \%$ of patients who do show a clinical response to gefitinib do not have these EGFR mutations, indicating that other, than these classical mutations, may confer sensitivity to TKIs, or that EGFR mutations are not the sole determinants of TKI response (Sharma et al, 2007). Since the original reports by Paez et al (2004) and Lynch et al (2004) several 'other' mutations of EGFR gene have been reported (Riely et al, 2006b). During sequence analysis performed by our group, several mutations of EGFR's exons 18, 19 and 21, other than 
the classical ones, which will be collectively reported in the text as 'other', have been identified; however, their biological as well as their clinical relevance is still unclear (Marchetti et al, 2005). The aim of the present study was to determine whether the presence of these 'other' variants is correlated with the clinical outcome of patients treated with gefitinib.

In the present study, the clinical outcome of NSCLC patients treated with gefitinib in the context of an expanded access program (EAP) was analysed according to the presence of classical or 'other' variants of EGFR mutations.

\section{PATIENTS AND METHODS}

\section{Patient selection}

Patients with histologically documented NSCLCs were included in this retrospective analysis. Additional inclusion criteria were as follows: a gefitinib treatment of at least 4 weeks (to evaluate efficacy after adequate exposure to the drug); complete information regarding tumour size, tumour location, extent of disease and prior treatments for NSCLC; bi-dimensionally measurable disease with imaging assessment performed at least 3 weeks before starting gefitinib therapy and at least one subsequent imaging assessment; tumour tissue was required for the assessment of EGFR mutations.

\section{Expanded access program}

Gefitinib EAP, was a non-randomised, open-label compassionate use program, which enrolled patients with advanced/metastatic NSCLC. The EAP protocol and informed consent forms were approved by the Scientific and Ethics Committees of the participating Institutions. Patient enrollment began on July 2001 and was closed on April 2006. Eligible patients with NSCLCs (aged $\geqslant 18$ years) were those who either (i) had disease progression with standard systemic chemotherapy or radiation therapy, or (ii) were ineligible for chemotherapy or radiation therapy, finally.

\section{Treatment}

Gefitinib was administered orally, as a once daily dose of $250 \mathrm{mg}$. Treatment was continued until disease progression, the appearance of unacceptable toxicity or patient's withdrawal of consent. Objective tumour responses were evaluated according to WHO response criteria (Miller et al, 1981).

\section{Immunohistochemistry}

Representative, tumour sections from formalin-fixed paraffinembedded (FFPE) tumour samples were stained immunohistochemically, as described previously (Koutsopoulos et al, 2007), using the mouse monoclonal anti-EGFR antibody (clone H11, code M3563, DakoCytomation, Glostrup, Denmark), in dilution $1 / 50$ and incubation time $1 \mathrm{~h}$ at room temperature. For the detection of antigen-antibody reaction the Ultra-Vision detection system AP Polymer kit (catalogue no. TL-125-AL, Lab Vision, Cheshire, UK), was used according to the manufacturer's instructions. Immunoreaction was considered as weakly positive $(2+)$ when more than $10 \%$ of the tumour cells showed weak to moderate complete membrane staining or as strongly positive $(3+)$ when a strong complete membrane staining was observed in more than $10 \%$ of the tumour cells. All other staining patterns were interpreted as negative ( 0 or $1+$ ) (Koutsopoulos et al, 2007).

\section{DNA extraction and mutation analysis}

All tumour samples were FFPE tissues. Representative sections from tissue used for DNA extraction were stained with H\&E and subjected to histopathologic examination. Subsequently, tissue samples were macrodissected or microdissected (piezo power Eppendorf Microdissector, Germany) to ensure that specimens contained at least $80 \%$ tumour cells. Approximately $5-10 \mu \mathrm{m}$ sections or 30-100000 cells were collected from normal (when available) and tumour samples and placed in $2 \% \mathrm{SDS} /$ proteinase $\mathrm{K}$ $\left(10 \mathrm{mg} \mathrm{ml}^{-1}\right)$ at $56^{\circ} \mathrm{C}$ overnight. DNA was extracted from the FFPE tissue using the MasterPure Complete DNA/RNA Purification kit (EPICENTRE; Biotechnologies, Madison, USA) according to the manufacturer's instructions. Exons 18, 19 and 21 were amplified and subjected to direct sequencing. The PCR primers were as follows:

155273L23(18ex) 5'-TCCCAAACACTCAGTGAAACAAA-3', 155348 L22(18ex) 5'-TGGTCTCACAGGACCACTGATT-3', 154838U22(18) $5^{\prime}$-TCAGAGCCTGTGTTTCTACCAA-3', 154899U20(18) 5'-TCCAA ATGAGCTGGCAAGTG-3', 55634U24(19ex) 5'-AAATAATCAGTGT GATTCGTGGAG-3'，156027L20(19) 5'-TGTGGAGATGAGCAGGG TCT-3', 156107L22(19ex) 5'-GAGGCCAGTGCTGTCTCTAAGG-3', 155750U20(19) $5^{\prime}$-GTGCATCGCTGGTAACATCC-3', 173160L22 (21Ex) 5'-CAGCTCTGGCTCACACTACCAG-3', 173076L19(21) $5^{\prime}$ CATCCTCCCCTGCATGTGT-3', 172656U22(21Ex) 5'-GCAGCGGG TTACATCTTCTTTC-3', 172747U19(21) 5'-GCTCAGAGCCTGGCA TGAA- $3^{\prime}$. The first PCR was carried out in total volume of $10 \mu \mathrm{l}$ containing $1 / 10$ of the extracted genomic DNA using $1 \mathrm{U}$ of Platinum Taq DNA polymerase (Invitrogen Corporation, Carlsbad, CA, USA). The initial denaturing step was $94^{\circ} \mathrm{C}$ for $15 \mathrm{~min}$, followed by 35 cycles of denaturing step at $94^{\circ} \mathrm{C}$ for $20 \mathrm{~s}$, annealing step at $60^{\circ} \mathrm{C}$ for $30 \mathrm{~s}$ and extension step at $72^{\circ} \mathrm{C}$ for $1 \mathrm{~min}$, ending with a final extension step at $72^{\circ} \mathrm{C}$ for $7 \mathrm{~min}$. Nested PCR was carried in a total volume of $20 \mu \mathrm{l}$ and the conditions were identical to the first PCR. Cycle sequencing reactions were performed using the nested PCR primers and the ABI BigDye Terminator kit (v3.1, Applied Biosystems, Foster City, CA, USA) and electrophoresed on an ABI3100 genetic analyzer (Applied Biosystems). Sequence variants were determined using the Seqscape software (Applied Biosystems) and confirmed by an independent PCR amplification and sequencing in both directions.

\section{Statistical analysis}

Descriptive statistics for the patient group are reported as median and range. Statistical comparisons between group rates (proportions) were assessed by Pearson's $\chi^{2}$-test or Fisher's test where appropriate (Altman, 1991). As this was a compassionate use program, the primary outcome variables were safety, survival and assessment of response. Overall survival (OS) was measured from entry into the study until death; 1-year survival was estimated using the Kaplan-Meier method (Collet, 1994).

\section{RESULTS}

\section{Patients' demographics}

Eighty-six patients with a median age of 61 years (range $=35-82$ ) were enrolled in the present analysis. Most of the patients (75\%) were male, $53(61.6 \%)$ had an adenocarcinoma histology and 61 (79\%) had stage IV disease. A total of $28(33 \%)$ patients were never-smokers. All patients had received a platinum-based chemotherapy, except two patients with severe heart failure, which precluded cisplatin administration. A total of 66 patients had gefitinib as third-line treatment; 14 patients $(21 \%)$ received taxanebased second-line therapy, $21(32 \%)$ a platinum-based therapy while the remaining $31 \quad(47 \%)$ received a gemcitabine or irinotecan-based regimen as second-line treatment. Patients' characteristics are presented in Table 1. EGFR membrane expression was assessed by immunohistochemistry in all tumour specimens; A total of $42(49 \%)$ of these specimens were considered as positive $(2+$ or $3+)$ for EGFR expression. 
Table I Patients' characteristics

\begin{tabular}{|c|c|c|}
\hline & $n$ & $\%$ \\
\hline \multicolumn{3}{|l|}{ Age } \\
\hline $\begin{array}{l}\text { Median } \\
\text { (minimum-maximum) }\end{array}$ & \multicolumn{2}{|c|}{$\begin{array}{c}61 \\
35-82\end{array}$} \\
\hline \multicolumn{3}{|l|}{ Sex } \\
\hline Male & 64 & 75 \\
\hline Female & 22 & 26 \\
\hline \multicolumn{3}{|l|}{ Histology } \\
\hline Adenocarcinoma & $47(53)$ & $55(61.6)$ \\
\hline Squamous cell carcinoma & $27(29)$ & $31(33.7)$ \\
\hline Large cell carcinoma & I & $1(1.1)$ \\
\hline Bronchoalveolar & 4 & $5(4.7)$ \\
\hline Other & 7 & $8(9.3)$ \\
\hline \multicolumn{3}{|l|}{ PS (WHO) } \\
\hline $0-1$ & 53 & 62 \\
\hline$\geqslant 2$ & 33 & 38 \\
\hline \multicolumn{3}{|l|}{ Stage } \\
\hline ॥B & 25 & 21 \\
\hline IV & 61 & 79 \\
\hline \multicolumn{3}{|l|}{ EGFR expression (IHC) } \\
\hline $0-1+$ & 44 & 51 \\
\hline $2-3+$ & 42 & 49 \\
\hline \multicolumn{3}{|l|}{ Line of therapy } \\
\hline 2nd & 20 & 24 \\
\hline$\geqslant 3 r d$ & 66 & 76 \\
\hline \multicolumn{3}{|l|}{ Smoking status } \\
\hline Smoker & 39 & 45 \\
\hline Ex-smoker & 19 & 22 \\
\hline Never-smoker & 28 & 33 \\
\hline \multicolumn{3}{|l|}{ No. of organs involved } \\
\hline 1 & 19 & 22 \\
\hline 2 & 48 & 56 \\
\hline$\geqslant 3$ & 19 & 22 \\
\hline Median (range) & $2(1-4)$ & \\
\hline
\end{tabular}

\section{Mutational analysis}

EGFR mutation detection was performed by sequencing exons 18 , 19 and 21 in tumours of all patients $(n=86)$ and matched-normal tissue $(n=22)$ or blood $(n=3)$ of patients carrying EGFR mutations.

According to the mutational status, three groups of patients were identified as follows: (i) the 'wild-type' group $(n=61$ patients; 71\%) with no detectable mutations; (ii) 'classical' mutations group $(n=11$ patients, $13 \%$; 6 of these patients harboured the classical exon 19 deletion, one the G719D, one the E746V and three the exon 21 L858R point mutation) and (iii) the 'other' mutations group ( $n=14$ patients, $16 \%)$. EGFR mutational status is presented in Table 2. None of the reported EGFR mutations was found in matched-normal tissues suggesting their somatic origin and eliminating the possibility to be singlenucleotide polymorphisms. A total of $8(57 \%)$ cases had 'other' mutations that have been previously reported and 6 cases had novel EGFR mutations.

A total of $1(1.1 \%)$ patient (no. 13) had two 'other' mutations, while $3(3.4 \%)$ patients (nos. 9, 11 and 18), who were included in the 'classical mutations' group, had both the exon 21 L858R mutation and an 'other' mutation (Table 3). The incidence of 'classical' mutations was gender - $(9.4 \%$ for males $v s 22.7 \%$ for females; $P=0.139)$ and histology $-(11.8 \%$ in adenocarcinomas $v s$ $14.3 \%$ in non-adenocarcinomas; $P=0.752$ ) independent, while it was significantly higher in 'never-smoker' patients compared to 'smokers' (32 vs $2.1 \%$, respectively; $P=0.001$ ). Similarly, regarding the 'other' variants, there was no difference in their incidence according to sex (male vs female: 18.8 vs 13.6\%, $P=0.750$ ), histology (adenocarcinoma vs other: 15.7 vs 20.0\%, $P=0.773$ ) and smoking habits (smoker $v s$ never-smoker: $20.8 v s$ 8.0\%, $P=0.200$ ). Finally, no correlation was observed between EGFR expression as assessed by IHC and presence of 'classical' mutations $(P=0.732)$; conversely, the detection of 'other' variants was more frequent in patients with tumours, which did not express EGFR by IHC (28.9 vs $8.3 \%, P=0.036$ )

\section{Treatment}

The median duration of gefitinib administration was 17 weeks (range $=4-140)$. The reason for treatment discontinuation was disease progression in all but six (6.9\%) patients (drug-related toxicity ( $n=3$ patients) and personal reasons non-related to treatment or the disease $(n=3$ patients)). There was no clear association between treatment duration and any of the following: PS $(P=0.262)$, histology $(P=0.751)$, disease stage $(P=0.103)$, smoking status $(P=0.950)$, sex $(P=0.663)$ and skin rash $(P=0.357)$ and EGFR expression by IHC $(P=0.254)$. However, patients belonging to the group with 'classical' mutations had significantly longer treatment duration when compared with patients of the 'wild-type' group (67 weeks $v s \quad 17$ weeks, respectively; $P=0.018$ ), while there was a trend towards longer treatment duration when compared with patients belonging to group of 'other' mutations (67 vs 21 weeks, respectively; $P=0.069$ ). On the contrary, there was no significantly different treatment duration between patients belonging to the 'other' mutations and those of the 'wild-type' group (21 and 17 weeks, respectively; $P=0.141)$.

\section{Response to treatment}

No patient achieved a complete response, while six (7.0\%) experienced a partial response (PR) (overall response rate $=7.0 \%$; $95 \% \mathrm{CI}=1.59-12.36)$ and $40(46.5 \%)$ stable disease $(\mathrm{SD})$; the disease control rate (DCR; PR + SD) was 53.5\% (95\% CI $=42.95-$ $64.03 \%$ ). Additionally, progressive disease (PD) was observed in 40 (46.5\%) patients. Disease control rate was significantly higher for the following: (i) patients with PS $0-1$ as compared with those with $\mathrm{PS} \geqslant 2$ (67 and 22\%, respectively; $P<0.001$ ); (ii) women as compared to men (77.3 and $42.9 \%$, respectively; $P=0.007$ ); (iii) never-smokers $v s$ smokers (84 and $34 \%$, respectively; $P<0.001$ ) and (iv) patients who developed skin rash as compared with those who did not (85.2 and $35.7 \%$, respectively; $P=0.003)$. In addition, there was a trend towards a higher DCR in patients with adenocarcinoma compared with those bearing other histologic types (54.9 and $47.1 \%$, respectively; $P=0.057$ ). Regarding patients achieving SD, significant association was observed for those with a PS of $0-1 \quad(P=0.003)$, never-smoker status $(P=0.001)$ and development of skin rash $(P=0.003)$; conversely, there was no association between DCR and $\operatorname{sex}(P=0.053)$ or histology $(P=0.355)$ (Table 4).

The DCR was significantly higher in patients of the 'classical' mutations than in patients of the 'wild-type' (90.9 and $43.3 \%$, respectively; $P=0.006$ ) group; conversely, there was no significant difference between the DCR observed in patients of the 'classical' mutations group and that of patients of the 'other mutations' group ( 90.9 and $57.1 \%$, respectively; $P=0.090$ ) or of patients of the 'other mutations' group and those of the 'wild-type' group (57.1 and 43.3\%, respectively; $P=0.386$ ). All patients (six out of six) with exon 19 deletion achieved disease control (two patients 
Table 2 Results of EGFR mutational analysis

\begin{tabular}{|c|c|c|c|c|c|c|c|}
\hline $\begin{array}{l}\text { Patients } \\
\text { no. }\end{array}$ & $\begin{array}{l}\text { 'Classical } \\
\text { mutations' } \\
\text { group }\end{array}$ & $\begin{array}{l}\text { 'Other } \\
\text { mutations' } \\
\text { group }\end{array}$ & Histology & Gender & Smoking status & Response & \\
\hline 1 & DEL 19 & & Squamous & Male & Never-smoker & SD & \\
\hline 3 & DEL 19 & & Adenocarcinoma & Male & Never-smoker & SD & \\
\hline 4 & & V8431 & Squamous & Male & Ex-smoker & SD & $\begin{array}{l}\text { V8431 reported (Koyama et al, } \\
\text { 2006) }\end{array}$ \\
\hline 6 & G719D & & Adenocarcinoma & Male & Never-smoker & SD & \\
\hline 7 & DEL 19 & & Adenocarcinoma & Female & Never-smoker & PR & \\
\hline 8 & & P69IS & Adenocarcinoma & Male & Ex-smoker & SD & Novel \\
\hline 9 & L858R, L86IP & & Undifferentiated & Male & Smoker & PD & \\
\hline 10 & & K860E & Squamous & Male & Smoker & PD & Novel \\
\hline 11 & L858R, V843I & & Adenocarcinoma & Female & Never-smoker & SD & \\
\hline 16 & E746V & & Adenocarcinoma & Female & Never-smoker & SD & \\
\hline 17 & & G729R & Undifferentiated & Male & Smoker & PD & $\begin{array}{l}\text { G729E reported (Willmore-Payne } \\
\text { et al, 2006) }\end{array}$ \\
\hline 18 & L858R, E709K & & Squamous & Female & Never-smoker & PR & \\
\hline 19 & & V726M & Adenocarcinoma & Male & Smoker & SD & Novel \\
\hline 20 & DEL 19 & & Adenocarcinoma & Male & Never-smoker & PR & \\
\hline 21 & DELI9 & & Squamous & Male & Never-smoker & SD & \\
\hline 22 & & G857E & Adenocarcinoma & Male & Smoker & $\mathrm{SD}$ & Reported (Hsieh et al, 2006) \\
\hline 23 & & E7IIK & Squamous & Male & Smoker & PD & Novel \\
\hline 24 & DELI9 & & BAC & Female & Never-smoker & SD & \\
\hline 25 & & G874S & Adenocarcinoma & Female & Smoker & $\mathrm{SD}$ & \\
\hline Total & 11 & 14 & & & & & \\
\hline
\end{tabular}

Table 3 Clinical characteristics of patients bearing both a classical and an 'other' mutation

\begin{tabular}{lllllr}
\hline Patients no. & Sex & Histology & Smoking status & Response to gefitinib & Duration \\
\hline 9 & Male & Undifferentiated & Smoker & PD & - \\
11 & Female & Adenocarcinoma & Never-smoker & SD & 64 weeks \\
18 & Female & Squamous & Never-smoker & PR & L858R-L86IP \\
\hline
\end{tabular}

Table 4 Clinical and molecular characteristics of patients achieving disease control

\begin{tabular}{|c|c|c|c|c|c|c|}
\hline & $n$ & Female sex $n(\%)$ & $\begin{array}{l}\text { Adenocarcinoma } \\
\text { histology } n \text { (\%) }\end{array}$ & $\begin{array}{c}\text { Never smoker } \\
n(\%)\end{array}$ & $\begin{array}{c}\text { Skin rash development } \\
n(\%)\end{array}$ & EGFR mutations \\
\hline PR & 6 & $4(67 \%)$ & $2(33 \%)$ & $5(83)$ & $4(67 \%)$ & $\begin{array}{l}\text { DEL 19: } n=2(33 \%) \\
\text { L858R: } n=1(17 \%) \\
\text { Wild type: } n=3(50 \%)\end{array}$ \\
\hline SD & 40 & 14 (35\%) & $28(70 \%)$ & 18 (45\%) & $19(47.5 \%)$ & $\begin{array}{l}\text { DEL 19: } n=4(10 \%) \\
\text { L858R: } n=1(2.5 \%) \\
\text { Other variant: } n=10(25 \%) \\
\text { Wild type: } n=25(62.5 \%)\end{array}$ \\
\hline
\end{tabular}

$\mathrm{PR}=$ partial response, $\mathrm{SD}=$ stable disease. ${ }^{\mathrm{a} B}$ Bronchoalveolar included.

achieved PR and four SD); in addition, two out of three patients with exon 21 L858R mutation experienced disease control (one patient with $\mathrm{PR}$ and one with SD) while both patients with the G719D and E746V point mutations achieved SD. In the multivariate analysis, the presence of mutations (either 'classical', or 'other', as well as all patients with mutations) did not emerge as a significant factor associated with DCR or SD.

\section{Time to tumour progression}

The median follow-up period was 109 weeks and the median time to tumour progression (TTP) 20 weeks (range $=4-140$ ). A total of $23(36 \%)$ patients had a TTP $>24$ weeks and $7(10.9 \%)>52$ weeks (Table 5). There was no difference in TTP according to sex $(P=0.468)$, histology $(P=0.676)$, EGFR positivity (by IHC) 
Table 5 EGFR mutation status for patients with $\geqslant 24$ and $\geqslant 52$ weeks TTP

\begin{tabular}{lrrrrr}
\hline TTP & n & Wild type & $\begin{array}{c}\text { Exon I9 } \\
\text { deletion }\end{array}$ & L858R & $\begin{array}{c}\text { Other } \\
\text { variant }\end{array}$ \\
\hline$\geqslant 24$ weeks & 23 & I| (48\%) & $5(22 \%)$ & $\mid(4 \%)$ & $6(26 \%)$ \\
$\geqslant 52$ weeks & 7 & | (14\%) & $2(29 \%)$ & $\mid(14 \%)$ & $3(43 \%)$ \\
\hline
\end{tabular}

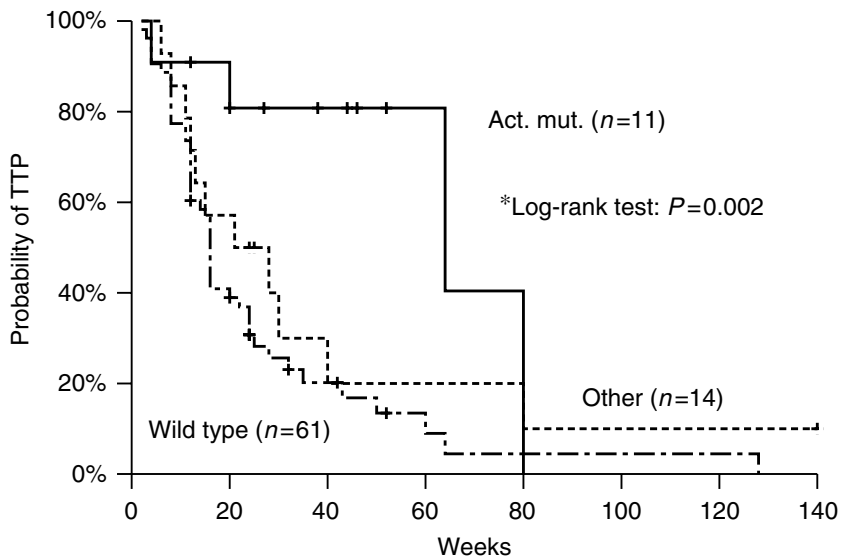

Figure I Kaplan-Meier curve of time to tumour progression (TTP) of wild-type EGFR patients group, 'classical' and 'other' mutations group. * $P$-value between 'classical' and wild type.

$(P=0.267)$ and PS $(P=0.437)$; conversely, patients who had neversmoked and patients who developed skin rash had significantly higher TTP $(P=0.003$ and $P=0.006$, respectively). Time to tumour progression in the 'classical' mutations group was significantly longer than in the 'wild-type' group (64 vs 16 weeks; $P=0.002$, Figure 1). On the contrary, there was no difference in TTP between 'other' mutations group and 'wild-type' group (21 vs 16 weeks; $P=0.363$ ) while there was a trend towards a significant difference in TTP between 'other' mutation group and 'classical' mutations group (21 vs 64 weeks; $P=0.069$ ). Although patients with DEL19 mutation had numerically higher TTP, when compared with L858R mutation patients, this difference failed to reach statistical significance ( $80 v s 64$ weeks, $P=0.786$ ).

\section{Survival}

Median OS was 48 weeks (range $=4-140$ ). None of the following factors had a significant impact on OS: PS $(P=0.403)$, histology $(P=0.198)$, smoking $(P=0.242)$, sex $(P=0.475)$, skin rash $(P=0.182)$ and EFGR IHC expression $(P=0.637)$. Median OS was significantly longer in patients with the DEL19 mutation (not reached) compared to 'wild-type' patients (36 weeks; $P=0.043$, Figure 2); however, when all patients with 'classical' mutations were included in the analysis, this difference was lost (78 vs 36 weeks; $P=0.052$, Figure 3 ); there was no statistically significant difference regarding OS between patients with DEL19 and L858R mutation (not reached vs 78 weeks, $P=0.896$ ). Similarly, patients of the 'other' mutation group had a median survival of 67 weeks, which was not different when compared with 'wild-type' group $(P=0.094)$ or 'classical' mutations group $(P=0.491)$. Efficacy results according to mutational status are presented in Table 6.

\section{DISCUSSION}

The incidence of the classical somatic mutations has been reported to range between 3 and $13 \%$ in Caucasian populations and between 30 and $40 \%$ in populations of Asian descent (Shigematsu et al,

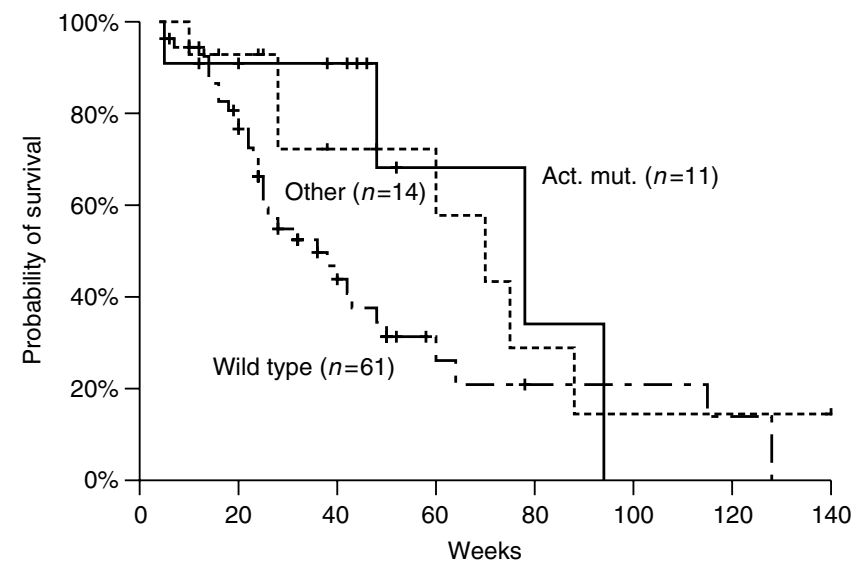

Figure 2 Kaplan-Meier survival curve of wild-type EGFR patients group 'classical' and 'other' mutations group.

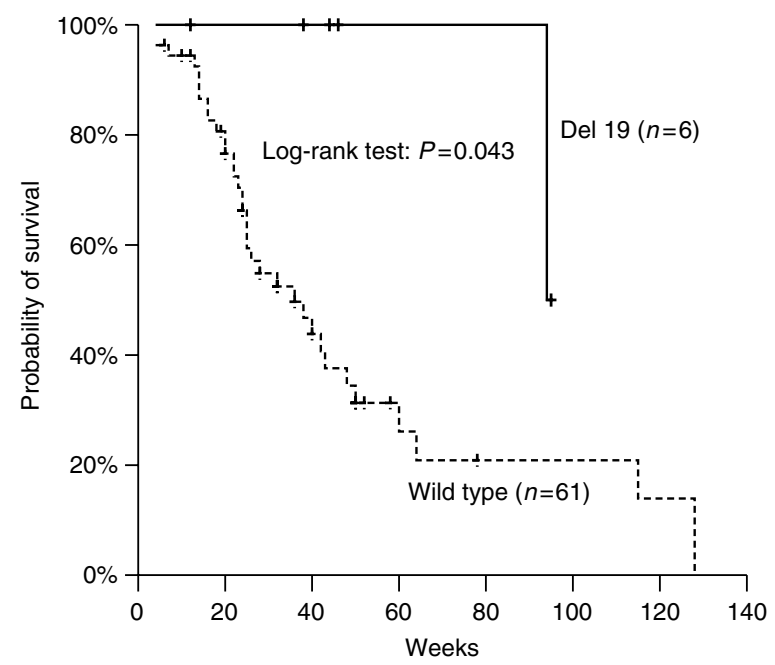

Figure 3 Kaplan-Meier survival curve of patients with the 'classical' DEL 19 mutation and wild-type EGFR.

Table 6 Efficacy results according to mutational status

\begin{tabular}{lccc}
\hline & 'Classical' mutations & 'Other' mutations & Wild type \\
\hline DCR & $90.9 \% *$ & $57.1 \%$ & 43.3 \\
TTP & 64 weeks* & 21 weeks & 16 weeks \\
OS & 78 weeks** & 67 weeks & 36 weeks \\
\hline
\end{tabular}

$\mathrm{DCR}=$ disease control rate, $\mathrm{OS}=$ overall survival; TTP = time to tumour progres sion. ${ }^{*} P<0.05$ (vs wild type). ${ }^{*} * P=0.052$ (vs wild type)

2005; Calvo and Baselga, 2006). In a Greek study (Murray et al, 2006), somatic mutations of EGFR were reported in $15 \%$ of a group of 60 patients with NSCLC, while Dova et al (2007) reported two mutations in 50 Greek patients with cancer of unknown primary. In our series, mutational analysis revealed the presence of 'classical' mutations in $11(13 \%)$ patients which is in agreement with other reports (Murray et al, 2006; Dova et al, 2007), while 14 $(16 \%)$ patients had 'other' mutations. A similar high incidence of 'other' EGFR mutations has been reported by Tsao et al (2005) who have also used microdissected FFPE tumour samples. Microdissection of tumour samples with a low percentage and/or uneven distribution of cancer cells allows the detection of mutations with higher sensitivity; this could be the reason for the high incidence of 
'other' mutations observed in our study. On the other hand, the low-DNA template input in PCR could generate false mutations. However, in our case the latter is unlikely, given that the sequence analysis of FFPE normal tissue specimens of 22 patients with EGFR mutations revealed no mutations (data not shown).

The presence of 'other' mutations in our study was not correlated with sensitivity to gefitinib. Indeed, patients whose tumours harbour 'other' variants of EGFR mutations had a higher, but not statistically significant, DCR when compared with patients bearing wild-type EGFR. However, this observation should be considered with caution given the small number of patients analysed. On the other hand, tumour growth control was significantly higher $(P=0.013)$ in patients who presented the classical EGFR mutations compared to that of patients with wildtype EGFR, as already has been reported (Argiris et al, 2003; Miller et al, 2004; Han et al, 2005; Kim et al, 2005; Thatcher et al, 2005; Tsao et al, 2005). Similarly, although patients with 'other' EGFR mutations had a numerically longer survival as compared with patients of the 'wild-type' group, this difference failed to reach statistical significance. This observation may suggest that, collectively, 'other' EGFR mutation variants per se could not be considered as predictors of clinical outcome.

Furthermore, there was a trend towards higher survival for patients with classical mutations, when compared with 'wild-type' patients, but this difference failed to reach statistical significance. A possible reason for this observation is the small number of patients studied. This observation is similar with that reported in the BR.21 study (Tsao et al, 2005) but it is in conflict with that reported by other studies (Hirsch et al, 2005; Takano et al, 2005).
However, patients with exon 19 deletions had significantly longer survival than patients of the 'wild-type' group; it should be interesting to mention that patients with EGFR exon 19 deletions are reported to have a longer survival than patients with EGFR L858R point mutations when treated with TKIs (Mitsudomi et al, 2005; Jackman et al, 2006; Riely et al, 2006a).

In the original reports by Lynch et al (2004) and Paez et al (2004), only one mutation per tumour was detected. However, subsequent studies demonstrated the presence of more than one mutation per tumour sample (Huang et al, 2004; Pao et al, 2004; Taron et al, 2005; Murray et al, 2006). In the present study, four patients had both a 'classical' and 'other' mutation variants; three of them achieved SD (Table 3). However, definitive conclusions cannot be drawn, given the small number of patients and the little amount of data presented in the literature.

In summary, our findings demonstrate that classical but not 'other' mutation variants of EGFR gene are associated with a higher DCR and better TTP; however, EGFR mutational status should not be considered as the only predictor of response to TKIs since disease control with gefitinib has also been observed in patients without EGFR mutations. Patients harbouring 'other' EGFR mutation variants have a clinical comportment comparable with that of patients with wild-type EGFR; although this observation strongly suggests that these mutations per se could not confer sensitivity to TKTs, we cannot exclude that some of these mutations could be of clinical relevance. Therefore, it should be of importance to establish a large international database of 'other' EGFR mutation variants, to better understand and evaluate their clinical relevance.

\section{REFERENCES}

Altman GD (1991) Practical Statistics for Medical Research. London, UK: Chapman and Hall

Argiris A, Mittal N, Masters G (2003) Gefitinib (ZD1839) as first line, compassionate use therapy in patients with advanced NSCLC. Proc Am Soc Clin Oncol 22; Abstract 2729

Bell DW, Lynch TJ, Haserlat SM, Harris PL, Okimoto RA, Brannigan BW, Sgroi DC, Muir B, Riemenschneider MJ, Iacona RB, Krebs AD, Johnson DH, Giaccone G, Herbst RS, Manegold C, Fukuoka M, Kris MG, Baselga J, Ochs JS, Haber DA (2005) Epidermal growth factor receptor mutations and gene amplification in non-small-cell lung cancer: molecular analysis of the IDEAL/INTACT gefitinib trials. J Clin Oncol 23: $8081-8092$

Calvo E, Baselga J (2006) Ethnic differences in response to epidermal growth factor receptor tyrosine kinase inhibitors. J Clin Oncol 24: 2158-2163

Carney DN (2002) Lung cancer - time to move on from chemotherapy. N Engl J Med 346: 126-128

Chou TY, Chiu CH, Li LH, Hsiao CY, Tzen CY, Chang KT, Chen YM, Perng RP, Tsai SF, Tsai CM (2005) Mutation in the tyrosine kinase domain of epidermal growth factor receptor is a predictive and prognostic factor for gefitinib treatment in patients with non-small cell lung cancer. Clin Cancer Res 11: $3750-3757$

Collet D (1994) Modelling Survival Data in Medical Research 3rd edn, Oxford: Blackwell Scientific

Dova L, Pentheroudakis G, Georgiou I, Malamou-Mitsi V, Vartholomatos G, Fountzilas G, Kolaitis N, Kitsiou E, Pavlidis N (2007) Global profiling of EGFR gene mutation, amplification, regulation and tissue protein expression in unknown primary carcinomas: to target or not to target? Clin Exp Metastasis 24: 79-86

Dziadziuszko R, Witta SE, Cappuzzo F, Park S, Tanaka K, Danenberg PV, Baron AE, Crino L, Franklin WA, Bunn Jr PA, Varella-Garcia M, Danenberg KD, Hirsch FR (2006) Epidermal growth factor receptor messenger RNA expression, gene dosage, and gefitinib sensitivity in nonsmall cell lung cancer. Clin Cancer Res 12: 3078-3084

Eberhard DA, Johnson BE, Amler LC, Goddard AD, Heldens SL, Herbst RS, Ince WL, Janne PA, Januario T, Johnson DH, Klein P, Miller VA, Ostland MA, Ramies DA, Sebisanovic D, Stinson JA, Zhang YR, Seshagiri S, Hillan KJ (2005) Mutations in the epidermal growth factor receptor and in KRAS are predictive and prognostic indicators in patients with non-

small-cell lung cancer treated with chemotherapy alone and in combination with erlotinib. J Clin Oncol 23: 5900-5909

Fukuoka M, Yano S, Giaccone G, Tamura T, Nakagawa K, Douillard JY, Nishiwaki Y, Vansteenkiste J, Kudoh S, Rischin D, Eek R, Horai T, Noda K, Takata I, Smit E, Averbuch S, Macleod A, Feyereislova A, Dong RP, Baselga J (2003) Multi-institutional randomized phase II trial of gefitinib for previously treated patients with advanced non-small-cell lung cancer. J Clin Oncol 21: 2237-2246

Han SW, Kim TY, Hwang PG, Jeong S, Kim J, Choi IS, Oh DY, Kim JH, Kim DW, Chung DH, Im SA, Kim YT, Lee JS, Heo DS, Bang YJ, Kim NK (2005) Predictive and prognostic impact of epidermal growth factor receptor mutation in non-small-cell lung cancer patients treated with gefitinib. J Clin Oncol 23: 2493-2501

Hirsch FR, Varella-Garcia M, McCoy J, West H, Xavier AC, Gumerlock P, Bunn Jr PA, Franklin WA, Crowley J, Gandara DR (2005) Increased epidermal growth factor receptor gene copy number detected by fluorescence in situ hybridization associates with increased sensitivity to gefitinib in patients with bronchioloalveolar carcinoma subtypes: a Southwest oncology group study. J Clin Oncol 23: 6838-6845

Hsieh MH, Fang YF, Chang WC, Kuo HP, Lin SY, Liu HP, Liu CL, Chen HC, Ku YC, Chen YT, Chang YH, Chen YT, Hsi BL, Tsai SF, Huang SF (2006) Complex mutation patterns of epidermal growth factor receptor gene associated with variable responses to gefitinib treatment in patients with non-small cell lung cancer. Lung Cancer 53: 311 - 322

Huang SF, Liu HP, Li LH, Ku YC, Fu YN, Tsai HY, Chen YT, Lin YF, Chang WC, Kuo HP, Wu YC, Chen YR, Tsai SF (2004) High frequency of epidermal growth factor receptor mutations with complex patterns in non-small cell lung cancers related to gefitinib responsiveness in Taiwan. Clin Cancer Res 10: $8195-8203$

Inoue A, Suzuki T, Fukuhara T, Maemondo M, Kimura Y, Morikawa N, Watanabe H, Saijo Y, Nukiwa T (2006) Prospective phase II study of gefitinib for chemotherapy-naive patients with advanced non-small-cell lung cancer with epidermal growth factor receptor gene mutations. J Clin Oncol 24: $3340-3346$

Jackman DM, Yeap BY, Sequist LV, Lindeman N, Holmes AJ, Joshi VA, Bell DW, Huberman MS, Halmos B, Rabin MS, Haber DA, Lynch TJ, Meyerson M, Johnson BE, Janne PA (2006) Exon 19 deletion mutations of epidermal growth factor receptor are associated with prolonged survival 
in non-small cell lung cancer patients treated with gefitinib or erlotinib. Clin Cancer Res 12: 3908 - 3914

Kim KS, Jeong JY, Kim YC, Na KJ, Kim YH, Ahn SJ, Baek SM, Park CS, Park CM, Kim YI, Lim SC, Park KO (2005) Predictors of the response to gefitinib in refractory non-small cell lung cancer. Clin Cancer Res 11: $2244-2251$

Koutsopoulos AV, Mavroudis D, Dambaki KI, Souglakos J, Tzortzaki EG, Drositis J, Delides GS, Georgoulias V, Stathopoulos EN (2007) Simultaneous expression of c-erbB-1, c-erbB-2, c-erbB-3 and c-erbB-4 receptors in non-small-cell lung carcinomas: correlation with clinical outcome. Lung Cancer 57: 193-200

Koyama N, Jinn Y, Takabe K, Yoshizawa M, Usui Y, Inase N, Miyake S, Yoshizawa Y, Hagiwara K, Kanazawa M (2006) The characterization of gefitinib sensitivity and adverse events in patients with non-small cell lung cancer. Anticancer Res 26: 4519-4525

Kris MG, Natale RB, Herbst RS, Lynch Jr TJ, Prager D, Belani CP, Schiller JH Kelly K, Spiridonidis H, Sandler A, Albain KS, Cella D, Wolf MK, Averbuch SD, Ochs JJ, Kay AC (2003) Efficacy of gefitinib, an inhibitor of the epidermal growth factor receptor tyrosine kinase, in symptomatic patients with non-small cell lung cancer: a randomized trial. JAMA 290: 2149-2158

Lynch TJ, Bell DW, Sordella R, Gurubhagavatula S, Okimoto RA, Brannigan BW, Harris PL, Haserlat SM, Supko JG, Haluska FG, Louis DN, Christiani DC, Settleman J, Haber DA (2004) Activating mutations in the epidermal growth factor receptor underlying responsiveness of non-small-cell lung cancer to gefitinib. $N$ Engl J Med 350: 2129- 2139

Marchetti A, Martella C, Felicioni L, Barassi F, Salvatore S, Chella A, Camplese PP, Iarussi T, Mucilli F, Mezzetti A, Cuccurullo F, Sacco R, Buttitta F (2005) EGFR mutations in non-small-cell lung cancer: analysis of a large series of cases and development of a rapid and sensitive method for diagnostic screening with potential implications on pharmacologic treatment. J Clin Oncol 23: 857-865

Miller AB, Hoogstraten B, Staquet M, Winkler A (1981) Reporting results of cancer treatment. Cancer 47: 207-214

Miller VA, Kris MG, Shah N, Patel J, Azzoli C, Gomez J, Krug LM, Pao W, Rizvi N, Pizzo B, Tyson L, Venkatraman E, Ben-Porat L, Memoli N, Zakowski M, Rusch V, Heelan RT (2004) Bronchioloalveolar pathologic subtype and smoking history predict sensitivity to gefitinib in advanced non-small-cell lung cancer. J Clin Oncol 22: 1103-1109

Mitsudomi T, Kosaka T, Endoh H, Horio Y, Hida T, Mori S, Hatooka S, Shinoda M, Takahashi T, Yatabe Y (2005) Mutations of the epidermal growth factor receptor gene predict prolonged survival after gefitinib treatment in patients with non-small-cell lung cancer with postoperative recurrence. J Clin Oncol 23: $2513-2520$

Murray S, Timotheadou E, Linardou H, Vrettou AV, Kostopoulos I, Skrickova J, Papakostantinou C, Christodoulou C, Pectasides D, Samantas E, Papakostas P, Skarlos DV, Kosmidis P, Fountzilas G (2006) Mutations of the epidermal growth factor receptor tyrosine kinase domain and associations with clinicopathological features in non-small cell lung cancer patients. Lung Cancer 52: 225-233

Paez JG, Janne PA, Lee JC, Tracy S, Greulich H, Gabriel S, Herman P, Kaye FJ, Lindeman N, Boggon TJ, Naoki K, Sasaki H, Fujii Y, Eck MJ, Sellers WR, Johnson BE, Meyerson M (2004) EGFR mutations in lung cancer: correlation with clinical response to gefitinib therapy. Science 304: 1497 - 1500

Pao W, Miller V, Zakowski M, Doherty J, Politi K, Sarkaria I, Singh B, Heelan R, Rusch V, Fulton L, Mardis E, Kupfer D, Wilson R, Kris M, Varmus H (2004) EGF receptor gene mutations are common in lung cancers from 'never smokers' and are associated with sensitivity of tumors to gefitinib and erlotinib. Proc Natl Acad Sci USA 101: 13306-13311

Riely GJ, Pao W, Pham D, Li AR, Rizvi N, Venkatraman ES, Zakowski MF, Kris MG, Ladanyi M, Miller VA (2006a) Clinical course of patients with non-small cell lung cancer and epidermal growth factor receptor exon 19 and exon 21 mutations treated with gefitinib or erlotinib. Clin Cancer Res 12: $839-844$

Riely GJ, Politi KA, Miller VA, Pao W (2006b) Update on epidermal growth factor receptor mutations in non-small cell lung cancer. Clin Cancer Res 12: $7232-7241$

Sharma SV, Bell DW, Settleman J, Haber DA (2007) Epidermal growth factor receptor mutations in lung cancer. Nat Rev Cancer 7: 169-181

Shepherd FA, Rodrigues PJ, Ciuleanu T, Tan EH, Hirsh V, Thongprasert S, Campos D, Maoleekoonpiroj S, Smylie M, Martins R, van KM, Dediu M, Findlay B, Tu D, Johnston D, Bezjak A, Clark G, Santabarbara P, Seymour L (2005) Erlotinib in previously treated non-small-cell lung cancer. $N$ Engl J Med 353: $123-132$

Shigematsu H, Lin L, Takahashi T, Nomura M, Suzuki M, Wistuba II, Fong KM, Lee H, Toyooka S, Shimizu N, Fujisawa T, Feng Z, Roth JA, Herz J, Minna JD, Gazdar AF (2005) Clinical and biological features associated with epidermal growth factor receptor gene mutations in lung cancers. J Natl Cancer Inst 97: 339-346

Stabile LP, Lyker JS, Gubish CT, Zhang W, Grandis JR, Siegfried JM (2005) Combined targeting of the estrogen receptor and the epidermal growth factor receptor in non-small cell lung cancer shows enhanced antiproliferative effects. Cancer Res 65: 1459-1470

Sunaga N, Tomizawa Y, Yanagitani N, Iijima H, Kaira K, Shimizu K, Tanaka S, Suga T, Hisada T, Ishizuka T, Saito R, Dobashi K, Mori M (2007) Phase II prospective study of the efficacy of gefitinib for the treatment of stage III/IV non-small cell lung cancer with EGFR mutations, irrespective of previous chemotherapy. Lung Cancer 56: 383-389

Takano T, Ohe Y, Sakamoto H, Tsuta K, Matsuno Y, Tateishi U, Yamamoto S, Nokihara H, Yamamoto N, Sekine I, Kunitoh H, Shibata T, Sakiyama T, Yoshida T, Tamura T (2005) Epidermal growth factor receptor gene mutations and increased copy numbers predict gefitinib sensitivity in patients with recurrent non-small-cell lung cancer. J Clin Oncol 23: $6829-6837$

Taron M, Ichinose Y, Rosell R, Mok T, Massuti B, Zamora L, Mate JL, Manegold C, Ono M, Queralt C, Jahan T, Sanchez JJ, Sanchez-Ronco M, Hsue V, Jablons D, Sanchez JM, Moran T (2005) Activating mutations in the tyrosine kinase domain of the epidermal growth factor receptor are associated with improved survival in gefitinib-treated chemorefractory lung adenocarcinomas. Clin Cancer Res 11: 5878-5885

Thatcher N, Chang A, Parikh P, Rodrigues PJ, Ciuleanu T, von PJ, Thongprasert S, Tan EH, Pemberton K, Archer V, Carroll K (2005) Gefitinib plus best supportive care in previously treated patients with refractory advanced non-small-cell lung cancer: results from a randomised, placebo-controlled, multicentre study (Iressa survival evaluation in lung cancer). Lancet 366: $1527-1537$

Tokumo M, Toyooka S, Kiura K, Shigematsu H, Tomii K, Aoe M, Ichimura K, Tsuda T, Yano M, Tsukuda K, Tabata M, Ueoka H, Tanimoto M, Date H, Gazdar AF, Shimizu N (2005) The relationship between epidermal growth factor receptor mutations and clinicopathologic features in nonsmall cell lung cancers. Clin Cancer Res 11: 1167-1173

Tsao MS, Sakurada A, Cutz JC, Zhu CQ, Kamel-Reid S, Squire J, Lorimer I, Zhang T, Liu N, Daneshmand M, Marrano P, da Cunha SG, Lagarde A Richardson F, Seymour L, Whitehead M, Ding K, Pater J, Shepherd FA (2005) Erlotinib in lung cancer - molecular and clinical predictors of outcome. $N$ Engl J Med 353: 133 - 144

Willmore-Payne C, Holden JA, Layfield LJ (2006) Detection of EGFR- and HER2-activating mutations in squamous cell carcinoma involving the head and neck. Mod Pathol 19: 634-640

Yoshida K, Yatabe Y, Park JY, Shimizu J, Horio Y, Matsuo K, Kosaka T, Mitsudomi T, Hida T (2007) Prospective validation for prediction of gefitinib sensitivity by epidermal growth factor receptor gene mutation in patients with non-small cell lung cancer. J Thorac Oncol 2: 22-28 